\title{
THE MUTUAL FUND AND ITS MANAGEMENT COMPANY: AN ANALYSIS OF BUSINESS INCEST
}

A RECENT wave of shareholder derivative actions ${ }^{1}$ against mutual fund ${ }^{2}$ directors and their management companies has challenged the independence and reasonableness of certain directors in granting fees to the funds' investment advisers-the management companies. The mutual fund sells its own shares to the public. Governed by the investment decisions of its management company, it then invests the proceeds in marketable securities. ${ }^{3}$ Typically, under its contract with the mutual fund, the management company receives as a fee for its services one-half of one per cent of the fund's total assets. ${ }^{4}$ The

1. There were about sixty derivative suits pending in March involving thirty funds. May, Observations, 193 The Commercial and Financial Chronicle 968 (1961).

2. Mutual funds are roughly classified as "open end" or "closed end." "Open-end companies are by definition those companies which are required to redeem their shares at net asset value on presentation by the shareholder. Most of these are continuously issuing and redeeming their shares, with a constantly increasing number of shares outstanding on balance." Jaretzki, The Investment Company Act: Problems Relating to Investment Advisory Contracts, 45 VA. L. REv. 1023 (1959). They differ from closed-end companies which issue their securities in substantial blocks and only on rare occasions. Ibid. Open-end funds permit the right of redemption to ensure the marketability of fund shares. See Prospectus, Dreyfus Fund, Inc., January 30, 1961, p. 10, published as an advertisement in N.Y. Times, March 19, 1961, $\$ 11$; N.Y. Times, May 9, 1960, p. 40, col. 4 (Most mutual funds "point with pride to the liquidity that is attached to the privilege of being able at all times to redeem shares with the funds themselves.") (Observations of A. Wilfred May, Executive Editor of the Comimercial and Financial Chronicle).

3. The fund's investment adviser may just furnish advice or actually determine what securities shall be purchased or sold. See Investment Company Act of 1940, 2 2(a) (19), 54 Stat. 793, 15 U.S.C. $\$ 80 a-2(a)(19)$ (1958). But the range of securities in which a fund may invest is limited by the fund's particular investment policy. Lobell, The Mutual Fund: A Structural Analysis, 47 VA. L. REv. 181, 182 (1961). For a discussion of the variety of fund investment policies, sec id. at $182 \mathrm{n} .4$; It is unlawful for a fund to change a stated policy without the approval of the fund's shareholders. See Investment Company Act of $1940, \S 13,54$ Stat. 811, 15 U.S.C. \$ 80a-13 (1958).

4. See Bus. Week, April 16, 1960, p. 158. For a statistical summary of the management fees of 249 mutual funds, see Lobell, Rights and Responsibilities in the Mutual Fund, 70

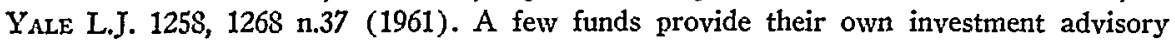
services. Taussig v. Wellington Fund, Inc., 187 F. Supp. 179, 209 n.117 (D. Del. 1960). In Japan most mutual funds are managed by brokerage houses, for which the only compensation is the commissions for buying or selling the fund's portfolio shares. Wall Street Journal, July 6, 1961, p. 1, col. 4. A potential danger of a broker performing management services is the temptation to "churn"-engage in unduly excessive buying and selling of the fund's securities in order to generate greater commissions. See Managed Funds, Inc., Securities Act Release No. 4122, at 12 (1959) (The average rates of portfolio turnover for all open-end investment company members of the National Association of Investment Companies were $15.8 \%$ in $1956,15.0 \%$ in 1957 , and $17.3 \%$ in 1958 as compared to the rates of turnover for Mlanaged Funds, Inc. of $70 \%, 44 \%$ and $97 \%$ for the corresponding years. The Commission concluded that the rates of share turnover "are unusually high for a mutual fund."). See 
continuous, substantial increase in the assets of most funds ${ }^{5}$ has driven these fees to levels challenged as excessive, unreasonable and wasteful of corporate assets. ${ }^{6}$

One commentator has recently challenged the basic assumption underlying the pending derivative suits. These suits presuppose a duty on the part of the directors to supervise the contractual relationship between the fund and its management company. But this commentator has cast doubt upon the existence of this duty, arguing that mutual fund shareholders are motivated to purchase shares of a given fund largely by a desire to secure the services of the fund's particular management company, just as a large investor selects a private investment counselor, and that the interposition of a third force- an active board of directors with power to terminate the fund's management or alter the compensation-would destroy the essentially personal relationship between the shareholder and the fund's management company. ${ }^{7}$ But the legislative history of the Investment Company Act of 1940 reflects an awareness of differences between the management company of a mutual fund and a personal investment counselor. ${ }^{8}$ Typically, the investment counselor supplies the

Bus. Week, July 25,1959 , p. 25-26 "The SEC charges contain a clear implication that the Managed Fund's portfolio was actively churned to provide commissions .....").

5. Examples of funds experiencing dramatic increases in the amount of their total assets are found among those involved in current litigation. See, e.g., Plaintiff's Complaint, p. 5, Ackert v. Fitzsimmons (Sup. Ct., N.Y.) (Investors Mutual, Inc., in 1959 had assets of $\$ 1,400,000,000$; in $1955, \$ 846,000,000$ ) ; Plaintiff's Complaint, p. 5, Ruskay v. Reed (Sup. Ct., N.Y.) (United Funds, Inc. assets increased from $\$ 273,000,000$ in 1955 to $\$ 748,000,000$ in 1959) ; Plaintiff's Complaint, p. 4, Saminsky v. Long (Sup. Ct., N.Y.) (Fundamental Investors, Inc. increased its assets from $\$ 256,200,000$ in 1954 to $\$ 599,300,000$ by 1959).

6. See, e.g., Plaintiff's Complaint, p. 7, Saxe v. Brady, (Del. Ch.); Plaintiff's Complaint, p. 8. Ackert v. Fitzsimmons, supra note 5; Plaintiff's Complaint, p. 13, Ruskay v. Reed, supra note 5 ; Plaintiff's Complaint, p. 8, Saminsky v. Long, supra note 5 . At publication, none of the cases involving an attack on the size of the management company fee has reached final adjudication. But cf. Meiselman v. Eherstadt, 170 A.2d 720 (Del. Ch. 1961). By failing to attack the size of the fee paid to the management company, plaintiffs conceded its reasonableness. $I d$. at 721 . Plaintiffs did allege, however, that the compensation received by fund officers and directors affiliated with the management company as a result of their personal shares in the company's revenues was excessive. Id. at 721-22. In addition, plaintiff tacitly admitted he could not prove the domination of the unaffiliated directors. Id. at 723. Compare note 32 infra. (Plaintiffs in the cases challenging the size of management company fees have alleged the domination of the non-affiliated directors.)

7. Lobell, Rights and Responsibilities in the Mutual Fumd, 70 YALE L.J. 1258, 1260, 1263-1272, 1279, 1281 (1961).

8. SEC, Report on Investarent Trusts and Investarent Conspantes : Investament Counsei, Investaient Management, Investurent Supervisory, and Investarent AdvisoRy SERvices [hereinafter cited as SEC REPORT] 26 (1939) ("The representatives of the industry emphasized that a marked distinction existed between the function of investment counselors and investment companies, although both types of organization in essence are formed to furnish investment management." ) ; See Hearings on S. 3580 Before a Subcommittee of the Senate Committee on Banking and Currency, 76th Cong., 3d Sess. 51 (1940) (testimony of David Schenker, Chief Counsel, SEC Investment Trust Study) [hereinafter 
wealthy individual with personalized service ${ }^{9}$ he generally does not buy and sell the securities in his client's portfolio; he merely imparts advice to the client, who retains managerial control over his own holdings. ${ }^{10}$ In contrast, many mutual fund shareholders are small, unsophisticated investors, ${ }^{11}$ who do not know even the identity of their fund's management company, ${ }^{12}$ and who,

cited as Senate Hearings] ; but cf. Hearings on H.R. 10065 Before a Subcommittee of the Committce on Interstate and Foreign Commerce, 76th Cong., 3d Sess. 109-10 (1940) (testimony of David Schenker).

9. See SEC REPoRt 25:

The function of investment counsel, as conceived by representatives of the industry, is to serve only a limited group of investors-those individuals and institutions with substantial funds who require continuous supervision of their investments and a program of investment to cover their entire economic needs.

See also id. at 25-26 (testimony of Dwight C. Rose and James N. White).

10. Id. at 26 (testimony of James $\mathrm{N}$. White).

[T] he ordinary investment trust . . . takes no cognizance of [its holder's] total financial position in investing his money for him, and is distinguished from investment counsel, in that it gives him no judgment in the matter whatever. In other words, advice and management are two entirely different things and I should say that the great bulk of our clients consider themselves as the managers of their capital.

11. Senatc Hearings 136 ("These securities ... are generally sold . . . as an alleged safe investment to people who understand saving but have little knowledge of investment") (testimony of Baldwin B. Bane, Director, Registration Division, SEC).

[S]o many of the investors in investment trusts are small investors, and in view of the fact that the primary social function of these trusts and their primary public usefulness is to serve the small investor. The small investor is often-although not always, of course-a rather unsophisticated investor ....

Id. at 769 (testimony of Professor E. Merrick Dodd, Jr.) : S. REp. No. 1775, 76th Cong., 3d Sess. 4, 9 (1940) (statistical analysis showing investment company certificate-holders are from economic classes unfamiliar with corporate practice). More recent appraisals confirm the above estimates. See Address by Senator Harrison A. Williams, Jr., Chairman of the Securities Subcommittee of the Senate Banking and Currency Committee, National Assaciation of Investment Companies, Oct. 14, 1960 as reported in N.Y. Times, Oct. 15, 1960, p. 29, col. 7 (referring to reports "indicating that the average purchaser has little or no understanding of the securities he buys"); Taussig v. Wellington Fund, Inc., 187 F. Supp. 179, 204 (D. Del. 1960) "a very considerable segment of the investing public are not informed investors ...") ; cf. Lobell, Rights and Responsibilities in the Mutual Fund, 70 Y ALE L.J. 1258, 1262 n.22 (1961) ("The number of fund accounts held by trustees, institutions, business organizations and other substantial and sophisticated investors has increased continually and as of the last quarter of 1960 stood at approximately 220,000 (as against 165,000 in the prior year). This number represents a relatively small percentage of the total number of mutual fund shareholders."). See $i d$. at 1258 n.4 ("The actual number of shareholders ... is estimated at about 3 million by the National Association of Investment Companies."). The account of the average shareholder of funds belonging to the National Association of Investment Companies averages $\$ 4,000$ and his median income is about $\$ 7,000$. See N.Y. World-Telegram, May 31, 1961, p. 28, col. 1.

12. Taussig v. Wellington Fund, Inc., 187 F. Supp. 179, 214 (D. Del. 1960) ("[T] his Court was surprised when two of defendants' expert witnesses, particularly knowledgeable in the investment company field, could not name Wellington Fund's investment adviser. No greater knowledge can be imputed to the investing public.") ; but see Lobell, Rights and Re- 
therefore, cannot be presumed to have purchased shares of a fund for the purpose of obtaining the services of its particular management company.

The same commentator has also argued that the mutual fund board should not be authorized or obligated to change the fee paid to the management company, because the fund's prospectus discloses the fee arrangement, thus enabling the potential shareholder to make an informed choice among competing funds, and then to approve the fee through his purchase. ${ }^{13}$ But prospectus disclosures about the management company's fees and past performance may be misleading. For example, a fund's increases in net assets may appear deceptively impressive, if not juxtaposed with comparable performance of other funds or the market generally. ${ }^{14}$ Also, a customer may be swayed by the amount of dividends received by the fund's shareholders, without understanding that such income might have been produced, not by dividend income received on the stock held by the fund, but rather from capital gains derived from the sale of stocks from its portfolio at capital gains-a course of conduct which may result in long term adverse effects. ${ }^{15}$ Additionally, prospectus dis-

sponsibilities in the Mutual Fund, 70 Y ALE L.J. 1258, 1263 n.22 (1961) ("even the less careful holder who knows of the fund only by its name, its objectives and performance record assumes a continuity of the adviser and his policy when he selects the fund's shares"); id. at 1269 (the typical mutual fund shareholder "chose the adviser who would do the managing"); id. at 1276 (the "statute recognizes the significance of the adviser's identity in the shareholder's choice of the fund shares"). Compare N.Y. Times, July 10, 1961, p. 33, col. S ("a well-known mutual fund expert ... received a call from a mutual fund salesman, saying a customer wanted to know what the 'load' [sales commission] was on 'Fund for the Republic'").

13. See Lobell, The Mutual Fund: A Structural Analysis, 47 VA. L. Rev. 181, 200, 202 (1961) ("disclosure and competition for investors' patronage should be the forces to adjust inequities in fee structure"); $i d$. at 209 ("disclosure and competition are the most efficient regulatory factors"). See also Lobell, supra note 12, at 1268-69 ("It would seem beyond doubt that no shareholder of a fund has standing to complain of any of these disclosed and accepted elements of the fund predating his purchase and unchanged (in terms or in material significance due to change in circumstances) since his acquisition of the shares"); id. at 1273-74 ("except in rare instances, the act of disclosure forecloses any complaint about the matters disclosed."). Federal legislation requires that a prospectus containing detailed information concerning the fund must be given to a purchaser before delivery of fund shares pursuant to a sale, Securities Act of 1933, $\$ 5$ (b), 48 Stat. 77, 15 U.S.C. $\$ 77$ (e) (b) (1958). For information required to be contained in the prospectus see $\$ 10,68$ Stat. 685,15 U.S.C. $\$ 77$ (j) (Supp. 1960). SEC Reg. C, 16 C.F.R. $\$ \$ 230.420-431$ (1949) prescribes rules regulating the content of prospectuses. For a summary of new disclosure rules enacted last year, see Wall Street Journal, Nov. 3, 1960, p. 28, col. 2; Bus. Week, Feb. 27, 1960, p. 123.

14. Cf. Forbes, Aug. 15, 1961, p. 15 ("sales literature is hardly objective and the ordinary performance charts have a serious flaw: they can only tell how much a fund has grown; they do not reveal how well.").

15. See Senate Hearings 156 (testimony of Baldwin B. Bane, Director, Registration Division, SEC) ("[Despite disclosure], consider the type of person to whom these securities are offered and sold. What does a return of capital mean to that person? Return of capital to them is just the same as dividends from income. They do not distinguish between them. That is true of some of these holders who are fairly well educated."); for an illustration of the relationship between a policy of realizing capital gain for the purpose of making 
closures may be obscured by aggressive selling techniques, ${ }^{16}$ including direct

distributions to shareholders and sales advantages, see Managed Funds, Inc., Securities Act Release No. 4122, at 13-14. The Commission cited evidence that the policy employed of realizing capital gain for the purpose of making quarterly distributions to shareholders was considered to be a "sales advantage ... very helpful [in the] growing phase" of the fund even though the unfavorable long term effects of this policy were fully appreciated.

16. Taussig v. Wellington Fund, Inc., 187 F. Supp. 179. 204 (D. Del. 1960) ("many investors are prone to rely heavily upon the particular dealer or representative who deals with them") ; Lobell, The Mutual Fund: A Structural Analysis, 47 VA. L. REv. 181, 208 n.79 (1961) ("[T]he type and degree of expectations by which the shareholder will measure the fund may well be those created by the salesman, apart from all the disclosures contained in the fund's literature and prospectus ....).

The SEC has prescribed regulations governing advertising and sales literature. In 1950, it issued a "Statement of Policy," amended in 1955 and 1957, which provides those who participate in the sale of mutual fund shares to the public with a guide as to the types of advertising and sales literature which the Commission considers violative of statutory standards. SEC Investment Company Act Releases Nos. 1503 (1950), 2086 (1955) and 2621 (1957).

The efficacy of internal policing of sales activities by the funds themselves has been questioned. See remarks of Keith Funston, President, New York Stock Exchange, N.Y. Times, Oct. 14, 1960, p. 52, col. 1 ("There still exists a certain number of people who operate in a vacuum of responsibility. The securities they handle may be excellent. The techniques by which they handle them sometimes are not."). Unlike the New York Stock Exchange, the National Association of Investment Companies lacks the power to police the selling activities of member concerns. See N.Y. Times, Aug. 22, 1960, p. 36, col. 3. The need for effective policing procedures of sales activities has been recognized by spokesmen for the mutual fund industry. Ibid. ("If we were policed by our own kind through practical interpretation of laws, there would be no trouble.") The use of dealers who are not associated with the fund's underwriting company and are not subject to the direct supervision of the underwriter has hampered attempts at internal regulation by the industry. See Bus. Week, Aug. 6, 1960, p. 118 ("There are too many opportunities for misrepresentation in the selling -intentional or not-if the salesmen aren't under your control.").

The use of part-time salesmen has been subject to strong criticism. See N.Y. Times, Oct. 14,1960 , p. 52, col. 1 (The public cannot be "adequately advised about selecting securities by someone who devotes only a small share of his business day to the complex problem of securities investment."). The National Association of Securities Dealers does not restrict part-time salesmen from membership provided they meet the regular membership requirements. N.Y. Times, Jan. 11, 1960, p. 57, col. 3. The National Association of Securities Dealers has defended its policy of admitting part-time salesmen. See remarks of William $\mathrm{H}$. Caflin, Chairman of the N.A.S.D., N.Y. Times, Nov. 6, 1960, Part III, p. 3, col. 3 ("If we were to restrict the privileges of becoming a N.A.S.D. member as to deprive an individual of the right of making a living we would make a mistake."). Similarly, mutual fund spokesmen have defended the use of part-time salesmen. See, e.g., N.Y. Times, Oct. 24, 1960, p. 42, col. 3 (remarks of Gerald S. Jeremias, President of the Empire Planning Corp.).

The investor is protected against fraud made in the offering of fund shares for sale. See Securities Act of 1933, \& 17, 48 Stat. 84, as amended, 68 Stat. 686 (1954), 15 U.S.C. 77q (Supp. 1960). Securities Exchange Act of 1934, \& 10, 48 Stat. 891, 15 U.S.C. $\$ 78 j$ (1958). See generally Loss, Securitres Regulation 806-76 (Student ed. 1951).

Despite the existence of aggressive sellings techniques, the mutual fund shareholder might be influenced by substantial advantages claimed by the funds. See, e.g., Prospectus, Dreyfus Fund, Inc., January 30, 1961, p. 4, published as an advertisement in N.Y. Times, March 19, 1961, § 11 (The Fund claims it offers the advantages of professional management, increased efficiency, and diversification.). 


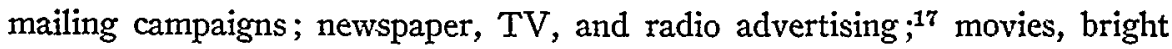
colored cartoons, ${ }^{18}$ musical lyrics ${ }^{19}$ and psychosociological "gimmicks."20 Congressional proponents of the Investment Company Act of $1940^{21}$ specifically found that the then existing disclosure requirements in the Securities Act of 1933 and the Securities Exchange Act of 1934 were inadequate to prevent malpractices-that "publicity [i.e. disclosure requirements] alone is insufficient to eliminate the abuses and deficiencies which exist in investment companies."22

One reason Congress thought disclosure requirements were insufficient in the mutual fund context, although satisfactory elsewhere, was probably the peculiar management company-mutual fund relationship. ${ }^{23}$ Often the management company is composed of the same individuals who create and dominate

17. See, e.g., N.Y. Times, Jan. $8,1961, \S 3$, pp. 6-7 (double full page advertisement); N.Y. Times, March 19,1961, \& 11 (a fourteen page special supplement, reprinting a prospectus). The success of such newspaper advertising and direct mailing campaigns is phenomenal. See N.Y. Times, Dec. 12, 1960, p. 48, col. 6 (orders received for one fund exceeded $\$ 1,200,000$ in two weeks of the initial offering period).

18. N.Y. Times, Sept. 5, 1960, p. 23, col. 2 .

19. N.Y. Times, May 30,1960 , p. 22 , col. 3.

20. N.Y. Times, May 9, 1960, p. 40, col. 3.

21. 54 Stat. 789,15 U.S.C. $\$ 80$ a (1958).

22. S. Rep. No. 1775, 76th Cong., 3d Sess. 4, 9 (1940). See also H.R. Rep. No. 2639, 76th Cong., 3d Sess. 10 (1940) ; see testimony of Robert E. Healy, Commissioner, Securities and Exchange Commission, Senate Hearings 203 ("[S]ome of the worst things that have happened in this particular industry, due to the fact that men with unsavory records and few scruples got control of them, have happened since the Securities Act of 1933 was passed and the disclosure features were not sufficient to prevent their doing it."). Cf. Rostow, To Whom and For What Ends is Corporate Management Responsible?, in THE CORPORATION IN MODERN SocIETY 54 (Mason ed. 1960) ("[N]o amount of disclosure can make corporate democracy effective where the corporate vote belongs to weak, scattered individual investors ... who cannot or will not take an effective part in the corporate electoral process.").

23. See SEC Holding Co. Act Release No. 1868, at 9-10 (1940), discussing a Report which was transmitted to Congress and which concluded that management contracts "are usually drafted and accepted by the sponsors themselves, or by directors of their own choosing, at the inception of the investment company and prior to the issuance of the company's securities to the public. In other words, the contracts are obtained in a self-dealing transaction in which no one represents the prospective shareholders of the investment company." Id. at 10. See testimony of David Schenker, chief counsel, SEC Investment Trust Study, Senate Hearings 251 (Aside from public utility holding companies, "I do not know of any other industry, financial institution, or any organization that has this system of management contracts .... Ordinarily in a corporation the managerial functions are performed by the officers and directors .... However, when we come to investment companies, we find the situation existing where the officers and directors, if they have not done it in toto, have delegated a substantial part of their management functions.") Cf. Address by Edward N. Gadsby, Chairman, Securities and Exchange Commission, Committee on Corporate Counsel of the Boston Bar Association, April 13, 1960, at p. 3. ("[U]neasiness stems from the anomaly presented by the management contracts which delegate to another entity many of the functions normally performed by the corporate board of directors."); Comment, The Investment Company Act of 1940, 50 YALE L.J. 440, 456 n.85 (1941). 
the mutual fund. ${ }^{24}$ Hence, in the absence of additional safeguards, the interests of prospective mutual fund shareholders may be undermined in the contract between the fund and its adviser. ${ }^{25}$ Congress enacted the Investment Company Act of 1940 in part to prevent the operation of investment companies "in the interest of ... investment advisers ... rather than in the interest of all classes of such companies' security holders ... ."20 The statute represented an attempt by Congress to prevent the fund's promoters from unjustifiably enriching themselves at the expense of the vulnerable shareholders. ${ }^{27}$

To curb adviser domination of the fund, ${ }^{28}$ section 10 of the Investment Company Act establishes a definite limit to the number of management company personnel who may serve on a mutual board of directors. If the management company is the fund's principal underwriter more than 50 per cent of the board directors must not be affiliated ${ }^{29}$ with the management company $;^{30}$ if the management company is not the fund's principal underwriter 40 per cent of the

24. See SEC Holding Co. Act Release No. 1868, at 9-10 (1940). See also Jaretzki, supra note 2, at 1024; Lobell, The Mutual Fund: A Structual Auralysis, 47 VA. L. Rev. 181, 184-85 (1961).

25. Cf. SEC Holding Company Act Release No. 1868, at note 23 supra; Senate Hearings 131 ("We say it is fundamental that these people who deal with investment trusts should not be able to do so if they control investment trusts.") ; Note, 41 Colurs. L. Rev. 269, 273 (1941) ; Compare Speech by Edward N. Gadsby, SEC Chairman, Boston Bar Association, April 13, 1960, p. 3 (The almost universal phenomenon of fund directors approving existing management contracts without even questioning the size of fee has been cited as evidence that the funds may have become "captives of particular advisors") ; Lobell, supra note 24 , at 211 ("[T] he possibility of a board veto [of a management contract] is practically nonexistent ....").

26. Section 1(b) (2), 54 Stat. 790 (1940), as amended, 15 U.S.C. $\$ 80 \mathrm{a}-1$ (b) (2) (1958).

27. See H.R. REP. No. 2639, 76th Cong., 3d Sess. 10 (1940) ("[T] his legislation is needed to protect small investors from breaches of trust upon the part of unscrupulous management") : S. REp. No. 1775, 76th Cong., 3d Sess. 6 (1940) (Provisions in the bill were designed to provide safeguard against the misappropriation and diversion of fund assets by unscrupulous managements of some companies.). Cf. note 11 supra; Address by Edward N. Gadsby, stpra note 23, at 3 ("The normal inertia of corporate shareholders seems, in investment companies, to be intensified both by this delegation of functions and by the fact that the average investment in a mutual fund is relatively small.").

28. See notes 23-27 supra and accompanying text.

29. A non-affiliated person must escape the classification of $\S 2$ (a) (3), 54 Stat. 791 (1940), 15 U.S.C. § \&a-2(3) (1958), which defines "Affiliated person" of another person as:

(A) any person directly or indirectly owning, controlling, or holding with power to vote, 5 per centum or more of the outstanding voting securities of such other person; (B) any person 5 per centum or more of whose outstanding voting securities are directly or indirectly owned, controlled, or held with power to vote, by such other person; (C) any person directly or indirectly controlling, controlled by, or under common control with, such other person; (D) any officer, director, partner, copartner, or employee of such other person; ( $E$ ) if such other person is an investment company, any investment adviser thereof or any member of an advisory board thereof; and $(F)$ if such other person is an unincorporated investment company not having a board of directors, the depositor thereof.

30. Section 10(b) (2), 54 Stat. 806 (1940), 15 U.S.C. $\$ 80 a-10$ (b) (2) (1958). 
board directors must not be affiliated. ${ }^{31}$ If it can be proven that an ostensibly non-affiliated director is actually controlled by the amnagement company, ${ }^{32}$ he becomes "affiliated" under the Act's definition. ${ }^{33}$ Thus while a given board

31. Section 10(a), 54 Stat. $\$ 06$ (1940), 15 U.S.C. $\$ 80 a-10(a)$ (1958).

32. Complaints filed in the current litigation have alleged that the required non-affiliated or outside directors are dominated by the affiliated directors. See, e.g., Plaintiff's Complaint, p. 11, Ruskay v. Reed, August 8, 1960, Supreme Ct., N.Y.; Plaintiff's Complaint, p. 9, Sarninsky v. Long, August 9, 1960, Supreme Ct., N.Y.; Brown v. Bullock, 194 F. Supp. 207, 212 (S.D.N.Y. 1961). Factors that courts have regarded as relevant in determining the existence of control over directors in other contexts should be applicable to the situation at hand. Some circumstances relevant to establishing domination include: (1) Selection or nomination of the director by the controlling party. Cf., Greene v. Allen, 35 Del. Ch. 242, 250, 114 A.2d 916, 917 (Del. Ch. 1955) ; Johnston v. Greene, 35 Del. Ch. 479, 485, 121 A.2d 919, 922 (Sup. Ct. Del. 1956) ; Guth v. Loft, Inc., 23 Del. Ch. 255, 274, 5 A.2d 503, 512 (Sup. Ct. Del. 1939) ; George Washington Memorial Park Ass'n v. Memorial Dev. Co., 139 N.J. Eq. 280, 282-83, 51 A.2d 221, 222-23 (1947). (2) Existence of family ties. In re Chicago Corporation, 28 S.E.C. 463, 466-68 (1948) ; Monterey Water Co. v. Voorhees, 45 Ariz. 338, 341, 43 P.2d 196, 197 (1935) ; George Washington Memorial Park Ass'n v. Memorial Dev. Co., supra at 223; In re J.P. Morgan \& Co., Inc., 10 S.E.C. 119, 122-38 (1941). Compare Commissioner v. Culbertson, 337 U.S. 733, 746-47 (1949). (3) Social relations. See Greene v. Allen, supra at 918; In re S.T. Jackson \& Co., SEC Securities Act Release No. 4459 at 14-22 (1950). (4) Former business associations between the director and the controlling person. Greene v. Allen, supra; of. In re J.P. Morgan \& Co., Inc., 10 S.E.C. 119, 122-38 (1941). (5) The amount of time spent by directors at meetings. Monterey Water Co. v. Voorhees, supra at 197 (no meetings held over a span of nearly three years). (6) Respective ages. George Washington Memorial Park Ass'n v. Memorial Dev. Co., stupra at 223; cf. Commissioner v. Culbertson, sutpra at 736. (7) Participation in recommending, evaluating, and terminating policies. In re North Country Uranium \& Minerals Ltd., 37 S.E.C. 608, 613 (1957); In re International Resources Corp., 7 S.E.C. 689, 716-17 (1940); In re Chicago Corporation, supra at 471; American Gas \& Elec. Co. v. SEC, 134 F.2d 633, 637 (D.C. Cir. 1943), cert. denied, 319 U.S. 763 (1943) ; Note, 60 Yale L.J. 311,316 (1951). (8) Independent knowledge of corporate affairs. See Globe Woolen Co. v. Utica Gas \& Elec. Co., 224 N.Y. 483, 490, 121 N.E. 378, 380 (1918).

33. Section 2(a) (3) (c), 54 Stat. 791 (1940), 15 U.S.C. \$ 80a-2(3)(C) (1958) provides that an "Affiliated" person is "any person directly or indirectly controlling, controlled by, or under common control with, such other person...." (emphasis added). Section 2(a) (9), 54 Stat. 791 (1940), 15 U.S.C. \$ 80a-2(9) (1958) provides that "A natural person shall be presumed not to be a controlled person within the meaning of this subchapter. Any such presumption may be rebutted by evidence, but except as hereinafter provided, shall continue until a determination to the contrary made by the Commission by order either on its own motion or on application by an interested person." This provision could be interpreted to require an SEC finding of control before a court could label a non-affiliated director affiliated because he had been controlled. In this event, a board could meet the requirements of $\S 10$ despite dominance of the non-affiliated directors unless the SEC had made a determination that the non-affiliated directors lacked independence. But, a more literal reading of this provision indicates an SEC determination is necessary only to rebut the presumption that a natural person is not a controlled person. So an SEC finding would not be necessary to establish control itself. If this interpretation is correct, plaintiffs in the current litigation can show that the board may be outside $\$ 10$ if they can prove the control of required non-affiliated directors-that the non-affiliated directors required by $\S 10$ must be independent or free of control by the investment adviser and not merely satisfy 
may have the required number of ostensibly non-affiliated directors to meet the standards of section 10, a finding of actual management company control under the statutory standard may reduce the number of non-affiliated directors below the required minimum. Section 15 (c) (1) of the statute, which empowers a majority of the non-affiliated directors to permit an investment company lawfully to "enter into, renew, or perform" a management contract ${ }^{34}$ immediately raises a question of statutory construction. Should the required majority be calculated on the basis of only those directors who, under the statutory standard, are found to be actually non-controlled even if this number falls below the minimum requirement of section $10,{ }^{35}$ or does the section 10 requirement constitute a minimum base from which this majority may be calculated? In other words if section 10 required a given fund to have 7 non-affiliated directors, 4 of whom were later proved to have been controlled, would the requisite majority be four (i.e. a majority of the required 7) or two (i.e. a majority of the actually non-affiliated 3 ) ? A reading of the statute which adopted the "actually non-controlled" directors as the calculating base without regard to the minimum

the technical requirements of $\$ 2$ (a) (3). Cf. Brown v. Bullock, 194 F. Supp. 207, 238 n.1, 240 (S.D.N.Y. 1961) ("[The provisions of the act envision] truly independent directors", aff'd, Docket No. 26948 (2d Cir. 1961) ("The force of these considerations is heightened by the pains taken in $\S 10,15$ U.S.C. $\S 80 \mathrm{a}-10$, to insure an adequate representation by independent directors."); Hearings on H.R. 10065 Before a Subcommittee on Interstate and Forcign Commerce, 76th Cong., 3d Sess. 109 (1940). In testifying on $\$ 10$ (b) (2), David Schenker, counsel to the SEC, stated:

In essence, what does that section provide? The section provides that if you are the manager or investment adviser of an investment company or an investment trust, then 40 percent of the board of directors have to be independent of you.

Now, why do we make that provision? You can see that the manager has a pecuniary interest in the method of running the trust, because his management fees may depend upon the performance of the trust. In order to furnish an independent check upon the management, the provision is made that at least 40 percent of the board must be independent of the management, officers and employees. I think that is one of the most salutary provisions in this bill. (emphasis added).

Jaretzki, The Investment Company Act of 1940, 26 WAS\#. U.L.Q. 303, 319-20 (1941) ("The theory of these provisions $[\$ \S 10,15,17]$ is (1) that it is desirable that all investment company transactions be subject to the scrutiny of at least a minority of directors indcpendent of the management and (2) that in cases where affiliations of directors might involve conflicts of interest, stockholders are entitled to the protection afforded by the existence of a majority of disinterested directors.") (emphasis added) ; Note, 41 Colum. L. REv. 269, 290 (1941) ("Instead of a complete separation of functions, the Act provides for an indepcndent majority on the board of directors, the function of which majority is to check any untoward activities on the part of those minority directors who are also serving the company in other capacities.") (emphasis added); Comment, 50 YALE L.J. 440, 446-47 (1941) ("Section 10 provides for an independent board of directors . . . ") (emphasis added).

34. Section 15(c), 54 Stat. 813, 15 U.S.C. § 80a-15(c) (1958). This power is "in addition to the requirements of subsections (a) and (b)." Ibid. Further approval of annual renewal, therefore, must be given by the board or by a majority of the outstanding voting securities. Section 15 (a) (2), 54 Stat. 812 , 15 U.S.C. $\$ 80 a-15$ (a) (2) (1958).

35. See notes $30 \& 31$ supra. 
requirements of section 10 would effectively deprive shareholders of the protective supervision of disinterested directors provided by the statutory scheme. ${ }^{38}$ To effectuate the purposes of the statute, therefore, section 10 should be read together with section 15 (c) (1) and any attempt to "enter into, renew, or perform" a management contract without the consent of a majority of the minimum number of non-affiliated directors required by section 10 should be considered violative of section 15 (c) (1)..$^{37}$

In addition to conferring the authority to "enter into, renew or perform" a management contract upon a majority of the non-affiliated directors, the statute in 15 (c) (2) alternatively confers this authority upon a majority of the outstanding voting securities of the fund..$^{38}$ But even if this alternative method of securing approval were employed, the resulting contract might still be void if enough ostensibly non-affiliated directors were actually controlled by the management company to reduce the total number of non-affiliated directors below the minimum requirements of section $10 .^{39} \mathrm{~A}$ contract might also be void although approved pursuant to section 15 (c) (1) by a majority of the required non-affiliated directors if the total number of non-affiliated directors did not meet the section 10 requirement. Arguably, these contracts would be invalid under section 47 (b) which voids "every contract made in violation of any provision of this subchapter . . . as regards the rights of any person who ... shall have ... engaged in the performance of any such contract . . . 240 Both subsections of $15(\mathrm{c})$ are addressed to "any registered investment company having a board of directors." And presumably, such a board, to be duly constituted, must meet the requirements of section 10.41

Furthermore, section 15 (c) (2) which permits shareholder approval as a method of entering into, renewing or performing a management company con-

36. See note 33 supra.

37. Moreover, violation of $\S 15$ (c) (1) could also be found, since the dominated directors would not have fulfilled the responsibilities implied by the grant of authority. See Brown v. Bullock, 194 F. Supp. 207, 235 (S.D.N.Y. 1961) (the grant of this defined power carries with it the corresponding "duty to determine whether or not the extension is desirable and in the best interest of the company .... The objectives of the Act would be nullified if the directors were free to extend mechanically the contract without honestly exercising their best judgment."), aff'd, Docket No. 26948 (2d Cir. 1961) (implication that in granting annual approval directors must give real consideration to the merits). For a criticism of these views, see Lobell, Rights and Responsibilities in the Mutual Fund, 70 Yale L.J. 1258, 1279-88 (1961) ; Brouk v. Managed Funds, Inc., 286 F.2d 901, 911-18 (8th Cir. 1961).

38. Section 15 (c) (2), 54 Stat. 813, 15 U.S.C. $\$ 80 a-15$ (c) (2) (1958). Shareholder approval is mandatory for the management company to serve initially as the investment adviser. Section 15 (a), 54 Stat. 812,15 U.S.C. $\$ 80 a-15$ (a) (1958).

39. See notes 30-31 supra. But cf., Senate Hearings 252 ("If [stockholders] want to pay a man a million dollars to manage the fund and if they know they are paying him a million dollars and if they have the right to approve the payment of a million dollars, this bill says that it is perfectly all right.").

40. Section 47 (b), 54 Stat. 846,15 U.S.C. $\$ 80 a-46$ (b) (1958).

41. See notes $30-33$ supra. 
tract 12 probably assumes the existence of a duly constituted board of directors. For acts of "approval" do not arise in a vacuum; they presuppose a tentative arrangement formulated under responsible and disinterested director supervision. ${ }^{43}$ If the Board is not duly constituted under section 10 it may lack the responsibility and disinterestedness to arrange the contract which the shareholders are empowered to approve.

Even if the shareholders or a majority of the non-affiliated directors approve the management contract, section 15(a) (3) still authorizes the Board to terminate the management contract at any time "without the payment of any penalty." Al Although Congress reduced the possibility of termination by requiring it to be exercised by a majority of the entire Board, including the directors with an interest in the management company rather than by a majority of just the unaffiliated directors, ${ }^{45}$ this provision, nevertheless, evidences an intent to have the directors exercise continuous close scrutiny over the fund's contractual relation with its management company; and in order for a contract to be lawful under the act, it must be subject to this safeguard. The presence of one "nonaffiliated" director beyond the number permitted by section 10 might, therefore, be sufficient to invalidate a contract under sections $47(\mathrm{~b}), 15(\mathrm{a})(3)$, and 10 taken together. Such a rigorous interpretation would afford shareholders the supervisory protection of the full number of non-affiliated directors prescribed by section 10 by providing a severe deterrent against any attempts at domination. The importance of this total protection is frequently recognized at common law in conflict of interests cases in analogous areas. In those cases some courts have invalidated board actions though a majority of the board, even without the "interested" directors' vote, approved ;" other courts have shifted

42. Section 15(c)(2), 54 Stat. 813 (1940), 15 U.S.C. § 80a-15(c)(2) (1958).

43. A fund's board of directors, for example, might write and recommend a contract for sharcholder approval. See Proxy Statement, pp. 8-9, Fundamental Investors, Inc., April 21, 1960. Cf. Proxy Statement, pp. 8-10, Investors Mutual, Inc., March 1, 1961 (Board recommended that stockholders oppose resolutions proposed by a shareholder concerning the management contract). On the advantage attending control of the proxy machinery, see note 50 infra.

44. Section 15(a)(3), 54 Stat. 812, 15 U.S.C. $\$ 80 a-15(a)$ (3) (1958). This power may also be exercised by a majority of the outstanding voting securities.

45. Section 15(a) (3), 54 Stat. 812 , 15 U.S.C. $\$ 80 a-15$ (a) (3) (1958).

46. See, e.g., Rothenberg v. Franklin Washington Trust Co., 127 N.J. Eq. 406, 413-14, 13 A.2d 667, 672 (1940). Cf. Globe Woolen Co. v. Utica Gas \& Elec. Co., 224 N.Y. $483,489,121$ N.E. $378,379-80$ (1918) ("A dominating influence may be exerted in other ways than by a vote"); Ini re Hirsch's Estate, 101 N.Y. Supp. 893, 899-900 (App. Div. 1906) (A trustee was removed, in part, because "he was elected president of the company by directors whose election he as trustee controlled and allowed them to vote him a large salary as such president, and also allowed them to authorize the payment to him of bills for the legal services which he rendered to the company. ... ) ; 2 REstatenent, Trusts $\$ 170$, at 366 (1959) ("A corporate trustee cannot properly sell trust property to one of its officers or directors. So also, it cannot sell trust property to another corporation where the directors are the same, or where so many of the directors of the two corporations are the same that there would be a substantial temptation to consider the advantage 
the burden of proving the fairness of the transaction to the directors. ${ }^{47}$ These judicial treatments are motivated by the theses that: (1) shareholders are entitled to have each board member forward only the company's interests 48 and (2) one director who participates in the discussion on a matter in which he has a selfish interest may improperly influence others. ${ }^{49}$

Moreover, if shareholder approval were to preclude an inquiry into the conduct of the directors the ease with which the fund's promoters can generally obtain such approval of a management contract ${ }^{50}$ would make it possible for the sponsors effectively to diminish the protection afforded by the non-affiliated directors requirement. ${ }^{51}$ For dissatisfied shareholders to oppose the renewal of

of the purchasing corporation rather than that of the beneficiaries of the trust.") ; but scc Church v. Harnit, 35 F.2d 499, 500 (6th Cir. 1929).

47. See Church v. Harnit, supra note 46, at 502; Baker \& Cary, CoRporatrons 437 (3d ed. 1958).

48. Klopot v. Northrup, 131 Conn. 14, 21, 37 A.2d 700, 703 (1944) ("The basis of [the rule] is that the benefit which may inure to the director personally, or to others having interests adverse to those of the corporation, affords ground for suspicion that he has not given to the corporation he represents and its stockholders the undivided loyalty which he owes to them.") Cf., Ballantine, Corporatrons 171 (rev. ed. 1946) ("It is the theory of disqualification [that a contract involving an interested director is void even though his presence was not required for a quorum or his vote for a majority] that the corporation is entitled to the advice of each of its directors and no one director may abdicate his duty.")

49. See Rothenberg v. Franklin Washington Trust Co., 127 N.J. Eq. 406, 413-14, 13 A.2d 667, 672 (1940). Silence on the part of an interested director may improperly influence other board members. See Globe Woolen Co. v. Utica Gas \& Elec. Co., 224 N.Y. $483,489,121$ N.E. $378,379-80$ (1918).

50. For illustrations of the majorities obtained in recent votes by fund shareholders, see, e.g., Defendant's Answer, pp. 4-6, Saxe v. Brady (Del. Ch.) (defendants assert that at a special meeting the shareholders of Fundamental Investors, Inc. approved the continuance of the existing management contract with 47,204,954 shares in favor and 425,671 opposed) ; N.Y. Times, March 22, 1961, p. 63, col. 4 (The stockholders of the One William Street Fund, Inc. approved continuance of its investment advisory contract with Lehman Brothers with $14,468,817$ or $98.3 \%$ of the shares counted in favor of the contract and 244,048 shares, or $1.7 \%$ against the contract.). On the apathy and disorganization of shareholders generally, see In re Chicago Corp., 28 S.E.C. 463, 474-75 (1948) (dispersion of stock ownership gives rise to 'controlling influence' by management or major minority stockholder; Berle \& Means, The Modern Corporation and Private Property 81 (1932) ; Rostow, To Whom and For What Ends Is Corporate Managenent Responsible?, in The Corporation in Modern Soctety 54 (Mason ed. 1960) (the electoral process is nothing more than an empty ritual); Dodd, Is Effective Enforcement of the Fiduciary Duties of Corporate Managers Practicable? 2 U. CHI. L. Rev. 194, 197-98 (1935). On the advantages attending control of proxy machinery, see BERLE \& MEANS, supra at 80-90, 139, 344-46; Emerson \& Latchem, Shareholder Democracy 41-42 (1957); Caplin, Proxies, Annial Meetings and Corporate Denocracy: The Lazeyer's Role, 37 VA. L. Rev. 653, 679-86 (1951) ; Hill, The Sale of Controlling Shares, 70 HARv. L. REv. 986, 996-98 (1957) (discussing power to frame proxies) ; SEC Holding Co. Act Release No. 1868, at 8 (1940) ("Control over the proxy machinery was shown to be a formidable device to secure the continued tenure of those in control.")

51. See notes $25,30-31,33$ supra. 
the management contract would involve a costly and, in all likelihood, futile proxy battle. ${ }^{52}$ An affirmative shareholder vote in support of the initial granting or subsequent extension of the management contract should not reduce the continuing responsibility of the directors in either refusing to renew or acting to terminate the contract. The composition of the fund's shareholders may radically change within a short period of time following shareholder approval as a result of sales and redemptions of shares of "open end" funds.53 If the directors were denied their full measure of statutory authority to act on questions pertaining to the management contract, many shareholders, who never had the opportunity to pass on the advisory contract, would be bound by its terms partially as a result of the affirmative votes of former shareholders who have terminated their association with the fund. Also, a shareholder who voted in faror of a management contract calling for an advisory fee of onehalf of one percent when the total amount paid was $\$ 500,000$ might not have anticipated that as a result of increased total assets the compensation might reach $\$ 2,000,000$ even though it is based on the same percentage stipulated in the contract for which he cast his affirmative vote. ${ }^{54}$

If a management contract is found void under the statute, a further question arises: how much of its fee should the management company be compelled to lisgorge? In Lutz v. Boas 55 the court found that "substantially all" of the advisory services had been performed by the fund's principal broker, with whom the fund had no valid contract. ${ }^{56}$ Since there had been no compliance with section 15 , the court compelled the broker to return all profits derived from its brokerage services but permitted it to retain expenses. ${ }^{57}$ The court ruled that remunerations of each of the firm's partners was properly allocable to profits, ${ }^{53}$ not expenses and, therefore, subject to disgorgement. By refusing

52. See note 50 supra.

53. See note 1 supra.

54. Cf. Plaintiff's Complaint, p. 5, Ruskay v. Read, August 8, 1960, Supreme Ct., N.Y. ( In 1960, United Funds, Inc. paid $\$ 3,500,000$ for investment advice as compared to $\$ 1,034,719$ paid in 1955); Plaintiff's Complaint, p. 4, Saminsky v. Long, August 9, 1960, Supreme Ct., N.Y. (The advisory fee paid by Fundamental Investors, Inc. increased from $\$ 1,019,466$ in 1954 to $\$ 2, \$ 25,340$ in 1959).; Plaintiff's Complaint, p. 3, Ackert v. Ausman, July 28, 1960, Supreme Ct., N.Y. (The investment advisory fee paid by Investors Mutual, Inc. was $\$ 7,022,043$ in 1959 as compared to $\$ 4,004,176$ in 1955). But cf. Lobell, Rights and Responsibilities in the Mutual Fund, 70 YALE L.J. 1258, 1284 (1961) ("The claim that a fee is exorbitant has little merit when asserted by a shareholder who accepted the same fee when he bought his shares originally and alleges no grounds for concluding that the fee is any more onerous to him now than it was then.").

55. Lutz v. Boas, 171 A.2d 381 (Del. Ch. 1961).

56. Id. at 388 .

57. Id. at 391. The court failed to find any authorities precisely in point on the question of damages. Cf. Goldstein v. Groesbeck, 142 F.2d 422, 426-27 (2d Cir. 1944). The court ruled that there should be recovery, the contract being void, but refused to determine the measure of damages in advance of trial on the merits.

58. 171 A.2d at 391 . 
to adopt as the fund's measure of recovery the difference between the fee paid and the value of the services performed by the recipient, the court successfully avoided the necessity of making very difficult calculations. ${ }^{59} \mathrm{By}$ so doing, the court also rejected a remedy which might have permitted a management company to profit from a contract void under the statute if it could show that the value of its services was at least equal to the compensation received. ${ }^{60} \mathrm{By}$ not requiring the repayment of expenses the court did not impose the most severe sanction available. But future courts, by refusing to allocate borderline items as expenses, can increase the deterrent effect of the sanction if this proves desirable.

In addition to holding the management company liable to the fund for any profit made in performing a void contract, consideration should be given to the possibility of imposing joint liability on each of the affiliated and non-affiliated directors who acquiesced in the award or performance of the contract. In Lutz v. Boas the court found that the two non-affiliated directors over whom jurisdiction was obtained "gave scant attention to the management" of the fund and were deemed jointly liable for the entire management fee awarded to an inactive investment adviser. ${ }^{61}$ If non-affiliated directors are held jointly liable for the damages recoverable by the fund, they would be encouraged to maintain their independence in supervising the fund's contractual relation with its investment adviser. ${ }^{62}$ Yet, the imposition of such liability might be regarded by some as too severe a penalty to be levied against directors who were merely unconcerned with the fund's affairs. In contrast, by holding only the affiliated directors who influenced the outside directors jointly liable, those who actively sought to subvert the policy of the statute would be punished. ${ }^{63}$

Although the Investment Company Act of 1940 specifically empowers the SEC to secure injunctive relief under certain conditions, ${ }^{64}$ it does not expressly

59. Cf. Forbes, August 15, 1961, p. 15 (Rating the performance of mutual funds "was a highly complex job. It involved the Forbes staff in well over 100,000 individual computations.").

60. Cf. Lutz v. Boas, 171 A.2d 381, 391 (Del. Ch. 1961) ("Since Model only charged such brokerage commissions as would have been charged by any other broker, it seems obvious that there can be no recovery if the court is to adopt the view that the damages are the difference between the consideration paid and the value of the services received.").

61. Id. at 396 (adopting language of the SEC in Managed Funds Inc., SEC Securities Act Release No. 4122, July 30, 1959, at 10.

62. Cf. Note, 70 Y ALE L.J. 1296, 1309 (1961) ("Since, by the act of authorizing or executing such unprofitable and expensive conduct, these individuals have displayed a certain indifference to corporate profits, the imposition of personal liability on such individuals may be as effective a deterrent as the imposition of shareholder liability on the corporation.").

63. Cf. In re Ira Haupt \& Co., 23 S.E.C. 589, 607 (1946) (Despite the absence of unusual profits, respondents were suspended from membership in the NASD for 20 days because "we cannot overlook the fact that respondent, in the course of a public distribution of securities, engaged in a willful violation of the Securities Act.").

64. Section 35(d), 54 Stat. 840 (1940), 15 U.S.C. \& 80a-34(d) (1958) (action to enjoin the use of a deceptive or misleading name); $\S 36,54$ Stat. $841,1940,15$ U.S.C. 
confer jurisdiction upon private parties to obtain redress for violation of one of its provisions. Nevertheless, the applicability of section 44 which grants jurisdiction to the federal and state courts to entertain "all suits in equity and actions at law brought to enforce any liability or duty created by . . . this [Act] ..." ${ }^{05}$ is not restricted to actions undertaken by the SEC. ${ }^{66}$ This phrase, as contained in an identical provision of the Holding Company Act, has been interpreted to embrace "any breaches of duty causing injury or loss to private persons." 67 Two additional grounds for recognizing federal jurisdiction over a private claim have developed under these statutes. Provisions comparable to section 47 (b), invalidating any contract made in violation of the act, have been held to create the right in a private person affected by an allegedly void contract to obtain judicial relief..$^{88}$ More broadly, the tort concept that the violation of a statute affords a remedy to an injured party for whose protection the statute was designed has been extended to enable plaintiffs to obtain federal jurisdiction for a claim based on the violation of a federal statute. ${ }^{69}$ In Brown v. Bullock ${ }^{70}$ the District Court relied on both of these grounds to uphold the right of the plaintiffs to allege in federal courts the domination of nonaffiliated directors and the granting of excessive fees to the management company. ${ }^{71}$ This result is at variance with that in the earlier case of Brouk $v$.

$\$ 80 a-35$ (1958) (action to enjoin a person from acting in a capacity in which he has committed "gross misconduct or gross abuse of trust"); § 42(e), 54 Stat. 843 (1940), 15 U.S.C. $\$ 80 \mathrm{a}-41$ (e) (1958) (action to enjoin practice constituting a violation of the act).

65. Section 44, 54 Stat. 844 (1940), 15 U.S.C. \& 80a-43 (1958).

66. Section 44, 54 Stat. 844 (1940), 15 U.S.C. $\$ 80 \mathrm{a}-43$ (1958). The Investment Company Act itself has been interpreted to permit a private cause of action. See Brown v. Bullock, 194 F. Supp. 207 (S.D.N.Y. 1961), aff'd, Docket No. 26948 (2d Cir. 1961); The Second Circuit's opinion rested on the implied duties contained in two sections of the Investment Company Act- $\$ 37$, 54 Stat. 841,15 U.S.C. \& 80a-36 (1958) (conversion) and $\$ 15$ dealing, in part, with the authority of directors regarding the fund's management contract. Taussig v. Wellington Fund, Inc., 187 F. Supp. 179, 216 (D. Del. 1960); Schwartz v. Eaton, 264 F.2d 195, 198 n.5 (2d Cir. 1959). Cogan v. Johnston, 162 F. Supp. 907 (S.D.N.Y. 1958). Contra Brouk v. Managed Funds, Inc., 286 F.2d 901 (8th Cir. 1961).

67. See Goldstein v. Groesbeck, 142 F.2d 422, 425 (2d Cir.), cert. denied, 323 U.S. 737 (1944) (construing $\S 25$, Public Utility Holding Company Act of 1935, 49 Stat. 835 (1935), 15 U.S.C. \& 79y (1958).

68. See generally Loss, Securities Regulation 1043-44 (1951); Goldstein v. Groesbeck, supra note 67 , at $426-27$ (provision is "incomplete, if not ineffective, unless it is considered to authorize recovery by the operating companies") ; Kardon v. National Gypsum Co., 69 F. Supp. 512, 514 (E.D. Pa. 1946) ("a statutory enactment that a contract of a certain kind shall be void almost necessarily implies a remedy in respect of it").

69. See Loss, op. cit. sutpra note 68, at 1044; 2 Restatenennt, Torts $\$ 286$; cf. Taussig v. Wellington Fund, Inc., 187 F. Supp. 179, 217 (D. Del. 1960) ; Texas \& Pac. Ry. v. Rigsby, 241 U.S. 33, 39 (1916) ; Fischman v. Raytheon Mfg. Co., 188 F.2d 783, 787 (2d Cir. 1951). But cf. Howard v. Furst, 238 F.2d 790 (2d Cir. 1956), cert. denied, 353 U.S. 937 (1957).

70. 194 F. Supp. 207 (S.D.N.Y. 1961), aff'd, Docket No. 26948 (2d Cir. 1961).

71. Id. at $223-24,247$. 
Managed Funds, Inc. ${ }^{72}$ The Brouk case, however, may be distinguished in that the defendant directors themselves were not alleged to have caused the violation of any specific provisions of the statute but instead were sought to be held for violations committed by others. ${ }^{73}$ The SEC appeared as amicus curiae in Brozen v. Bullock and successfully urged the granting of jurisdiction. ${ }^{74}$ By pointing out that, as presently constituted, it was only able to examine thoroughly the "affairs of mutual funds at a rate at which it would take over twenty years to inspect all the funds now registered with the Commission," the SEC indicated that adequate enforcement of the staute could not be expected if private parties were not permitted recourse to the courts to combat alleged violations. ${ }^{75}$

In addition to alleging domination of non-affliated directors, plaintiffs in the current litigation are urging that management company compensation has been excessive. If a court finds no domination under the provisions of the statute, however, it would probably be reluctant to hold for the plaintiffs on the issue of excessive fees. ${ }^{76}$ In cases involving challenges to the amount of executive compensation awarded corporate employees, courts have reiterated the proposi-

72. 286 F.2d 901 (8th Cir. 1961).

73. Id. at 918 (complaints seek to hold directors to strict liability as insurers); id. at 912 (rejects liability of directors for violations of the Acts by others). These statements were used by the District Court in Brozen v. Bullock to distinguish the Brouk case. $194 \mathrm{~F}$. Supp. at 247. The Second Circuit in Brozun v. Bullock refused to rule on whether the Brouk case was adequately distinguished and disagreed with its holding so far as it might not be distinguishable. Docket No. 26948, at 2815 (2d Cir. 1961).

74. 194 F. Supp. 207, 210 (S.D.N.Y. 1961), aff'd, Docket No. 26948 (2d Cir. 1961).

75. Oral argument in Brown v. Bullock (reconstructed in letter from Walter P. North, Assistant General Counsel, SEC, to the Yale Law Journal, Sept. 15, 1961, on file in the Yale Law Library). Cf. Brown v. Bullock, supra note 74, at 229 (reference to "the law-enforcement aspects of private litigation based on statutory violations"). For a review of the SEC's inspection program of investment companies, see 1960 SEC Awn. REP. 170. Cf. Jaretzki, The Investment Company Act: Problems Relating to Investment Advisory Contracts, 45 VA. L. REv. 1023, 1037 (1959) ("The Commission itself would doubtless be reluctant to undertake [the] tremendous additional burden [of regulating advisory fees].").

76. See Meiselman v. Eberstadt, 170 A.2d 720, 723 (Del. Ch. 1961); Gallin v. National City Bank, 152 Misc. 679, 705-06, 273 N.Y. Supp. 87, 117 (Sup. Ct. 1934) ("The rule is established that directors of a corporation acting as a body in good faith have a right to fix compensation of executive officers for services rendered to the corporation, and that ordinarily their decision as to the amount of compensation is final except where the circumstances show oppression, fraud, abuse, bad faith, or other breach of trust.") ; Heller v. Boylan, 29 N.Y.S.2d 653, 680 (Sup. Ct. 1941), aff'd without opinion, 263 App. Div. 815, 32 N.Y.S.2d 131 (1941) ; Latrin, CoRporatrons 237 (1959) (". . . where the officer-director's salary is determined without his participation by disinterested members of the board, wide scope is given to the discretion of this disinterested group"); Ballantine, Corporations § 76, at 192 (rev. ed. 1946) ("Courts will not undertake to review the fairness of official salaries, at the suit of a shareholder attacling them as excessive, unless wrongdoing and oppression or possible abuse of fiduciary position are shown."). 
tion enunciated by the Supreme Court in Roger $v$. Hill ${ }^{\mathbf{7 7}}$ that compensation must bear a relation to the services rendered. ${ }^{78} \mathrm{But}$, in ascertaining the reasonableness of compensation in particular situations, courts understandably have been reluctant to substitute their business judgment for that of an independent board of directors. ${ }^{79}$ Nevertheless, a court might possibly determine that the compensation of a management company is excessive in a given situation. Courts have not hesitated to intervene when the recipient failed to perform any services. ${ }^{80}$ Also, many executive compensation cases have involved salaries or bonuses which were tied to a yardstick such as corporate earnings which bear a fairly close relationship to the value of the recipient's services. ${ }^{81}$ When compensation has been geared to a more dubious barometer of the value of management services, such as the stock market behavior of the corporation's shares, courts have been less reluctant to sustain the plaintiffs. ${ }^{82}$ The size of a mutual fund's assets, which, to a large degree, may be a product of a successful selling techniques unrelated to the quality of the adviser's services, ${ }^{\text {s3 }}$ should be regarded as an unreasonable measure of compensation.

77. 289 U.S. 582 (1933). See LatTin, CoRporatrons 237 (1959).

78. Rogers v. Hill, supra note 77, at 591 (adopting Judge Swan's dissent below in 60 F.2d 109, 113 (2d Cir. 1932).

79. See note 76 supra.

80. See Cullen v. Governor Clinton Co., 279 App. Div. 483, 486, 110 N.Y.S.2d 614, 617 (1952) (a grant of salary to individuals who also received a management fee was "wasteful of corporate funds" since the corporation would expect to get for the fee paid under the management contract the desired services); Eshleman v. Keenan, $21 \mathrm{Del}$. Ch. 259, 264-67, 187 A.2d 25, 27-29 (1936), aff'd, 23 Del. Ch. 234, 2 A.2d 904 (1938).

81. See Heller v. Boylan, 29 N.Y.S.2d 653, 679 (Sup. Ct. 1941) upholding a bonus plan for officers based on corporate earnings. " Under the plan the stockholders prosper with the officers, the increased earnings of the stockholders work increased earnings for the officers. The plan is by no means one-sided; it is largely contingent upon and measured by success. The design of the plan was to induce the profits to mount."); Gallin v. National City Bank, 152 Misc. 679, 703, 273 N.Y. Supp. 87, 113 (Sup. Ct. 1934) ("We have long since passed the stage in which stockholders, who merely invest capital and leave it wholly to management to make it fruitful, can make absolutely exclusive claim to all profits against those whose labor, skill, ability, judgment, and effort have made profits available. The reward, however, must have a reasonable relation to the value of the services for which it is given...").

82. See Berkwitz v. Humphrey, 163 F. Supp. 78, 90 (N.D. Ohio 1958) (Since "the market value of stock is governed by many factors unrelated to the services of employees of a corporation ... the plan here in question bears no evidence of any purpose to equate compensation with the value of services."). But cf. Lieberman v. Koppers Co., 149 A.2d 756, 759-60 (Del. Ch. 1959), aff'd sub nom. Lieberman v. Becker, 155 A.2d 596 (Del. 1959).

83. For a discussion of aggressive selling techniques, see notes 16-20 supra. The distribution of fund shares is conducted through sales organizations designed to reach a mass market. Bookman, How Good Are Mutual Finds?, Fortune, June, 1960, pp. 144, 190. The success of the selling techniques used to increase sales and thereby augment assets is demonstrated by statistics showing the tremendous rise in sales of fund shares in recent years. See Forbes, August 15, 1961, p. 15 (At the present time the assets of mutual funds exceed $\$ 20$ billion as compared to $\$ 2.5$ billion in 1950 and $\$ 1$ billion in 1940.) Cf. testimony 
By inducing a dealer to concentrate his efforts upon the selling of shares of a particular fund, even though the fund's performance may compare unfavorably with that of other funds whose shares have also been placed at the dealer's disposal for public distribution, that fund may augment its assets, thereby reducing any correlation between the size of its assets and the value of its advisory services. ${ }^{84} \mathrm{~A}$ fund might engage in the practice of "reciprocal brokerage," agreeing to funnel a percentage of the fund's brokerage business in buying and selling securities for its portfolio to a particular dealer commensurate with his success in selling fund shares. ${ }^{85} \mathrm{~A}$ fund might also reward cooperative dealers by giving them shares of stock in the fund's management company if the company is publicly owned. ${ }^{86}$ The fund's underwriter, usually

of Robert E. Healy, SEC Commissioner, in Senate Hearings 47 ("What we ought to develop is a group of expert investment trust managers who do not make their profits from originating and distributing types of securities, styled principally for their sales appeal, but from wise and careful management of the funds entrusted to them.") The amount of sales in a "closed end" fund or the ratio of sales to redemptions in an "open end" fund are not the only factors which determine the amount of a fund's assets. The market performance of securities held in the fund's portfolio is also highly relevant. Under traditional trust law concepts, however, the size of the trust property is a relevant factor in determining the amount of compensation which will be awarded to a trustee. See RESTATEMENT, Trusts $§ 242$, at 606 (2d ed. 1959) ; Bogert, Trusts $\$ 144$, at 551 (3d ed. 1952) ; 3 SCoTr, TRusts $\$ 242$, at 1929 (2d ed. 1956).

84. There does not appear to be a close correlation between the size of a fund and the quality of its management results. See Forbes, supra note 83, at 17-23.

85. The effect of such reciprocal arrangements is "to channel a mutual fund's brokerage business through the Wall Street firms in rough proportion to the amount of the fund's shares that these brokers sell." Bus. Week, July 25, 1959, p. 25. The constant pressure on the funds for more "payola" can be a temptation to turn over their security portfolios simply to create more commissions. See Bookman, supra note 83, at 185 . The existence of this practice might call for additional regulatory legislation. See Bus. Week, supra at p. 26 ("Eventually we may ask Congress for additional legislation to control the way reciprocal business is parcelled out. It's clear that at any time a fund's investment manager decides to buy or sell for the benefit of a broker, instead of for his shareholders, he's violating his fiduciary responsibility.") (remarks of Joseph C. Woodle, director of SEC's Division of Corporate Regulation).

86. See remarks of Walter G. Damroth, President, Templeton, Damroth Corp., a mutual fund management company, in N.Y. Times, Sept. 28, 1959, p. 48, col. 3 ("By offering them [dealers] shares, they have a real reason for continued interest in the fund business itself. It also adds dealer incentive.") Shares in publicly held management companies command unusually high prices. Examples illustrating the tremendous appreciation of management company shares may be found in Bus. Week, Sept. 5, 1959, p. 88; Bus. Week, May 16, 1959, p. 155. For a picture of the market performance of representative management company shares since Jan. 1, 1960, see May, Observations, 193 Consmercial and Financial Chronicle 968 (1961) (The average gain in management company shares was 28 per cent whereas the Dow Jones Industrial Average increased by only 7 per cent.). These market prices can be attributed, in part, to the expectation of the purchasers that the mangement company will remain indefinitely as the fund's adviser. Lobell, The Mutual Fund: A Structural Analysis, 47 VA L. Rev. 181, 198 (1961); Jaretzki. The Investment Company Act: Problems Relating to Investment Advisory Contracts, $45 \mathrm{VA}$. L. REv. 1023, 1031 (1959). 
the recipient of a substantial portion of the sales commission paid by the customer, may permit dealers to retain a greater percentage of the commission than that allowed by competing funds. ${ }^{87} \mathrm{~A}$ fund may encourage dealers to favor its shares by permitting them to receive a disproportionately large percentage of the total commission at the time of initial payment instead of equal amounts spread over the entire contractual period. 88

The overall performance of the mutual fund might be more relevant in evaluating the reasonableness of management company compensation ${ }^{89}$ than

87. See Greene, The Uniform Offering Price of Mutual Fund Shares Under the Investment Company Act of 1940, 37 U. DET. L.J. 369, 387 (1960).

88. Most funds charge the buyer of fund shares a commission or "load" equal to 7 or 8 $\%$ of his total purchase. Bus. Week, Jan. 17, 1959, p. 86. The Investment Company Act of 1940, § 27(a) (1), 54 Stat. 829 (1940), 15 U.S.C. § 80a-27(a)(1) (1958) prescribes a maximum sales load of $9 \%$ for periodic payment plans. Section 22(b), 54 Stat. 823 (1940), 15 U.S.C. $\$ 80 a-22$ (b) (1958) authorizes the adoption of rules by the National Association of Security Dealers to bar "an unconscionable or grossly excessive sales load." Under section 22(c), 54 Stat. 823 (1940), 15 U.S.C. \& 80a-22(c) (1958), the SEC may promulgate rules for the same purpose. Some funds do not charge any commission. Bus. Week, Feb. 20, 1960, pp. 166, 169. These funds do not have sales organizations and are not really in competition with conventional mutual funds. Bus. Week, July 5, 1958, p. 68. The typical $8 \%$ sales charge is usually divided $3 \%$ to the salesman, $3 \%$ to the dealer and $2 \%$ to the distribution company. Bookman, supra note 83 , at 144,183 . Under contractual plans, part of the total commission charge is prepaid in the first year but the amount paid cannot exceed half of the total payments for the first year. Bus. Week, Jan. 17, 1959, p. 86 . Thus, under a ten year contractual plan providing for 10 yearly payments of $\$ 1,000$ a buyer might have to pay as much as a $\$ 500$ commission or "front end load" in the first year. In contrast, if the plan were not contractual but voluntary the commission paid during the first year could not exceed $\$ 90$. See Bookman, supra note 83, at 190 . The fund's stress on the liquidity of fund shares through exercise of the right of redemption on the one hand, and the inducement to retain fund shares fostered by paying disproportionate commission charges in the first year on the other, has been described as the "schizophrenic liquidity attitude." N.Y. Times, May 9, 1960, p. 40, col. 4 (observation of A. Wilfred May, executive editor of the Commercial and Financial Chronicle); see also summarized observations of Walter Benedick, president of Investors Planning Corp., in Bus. Week, Aug. 6, 1960, pp. 115, 118 ("One reason the contractual plan has been expanding so fast is that it offers salesmen a "front-end" load in which almost half the total commission is collected in the first year. ... because the initial earnings are so high, the salesmen have adequate incentive to go out and open up new markets".) For statistics indicating the growth of contractual plans, see N.Y. Times, March 14, 1960, p. 40, col. 3. Investors are opening new mutual fund accumulation plans at the rate of $\$ 30,000$ a month. N.Y. Times, June 6 , 1960 , p. 44, col. 5.

89. See Meiselman v. Eberstadt, 170 A.2d 720, 723 (Del. Ch. 1961); Winkelman v. General Motors Corp., 44 F. Supp. 960, 969-70 (S.D.N.Y. 1942) ; Epstein v. Schenck, 35 N.Y.S.2d 969, 979 (Sup. Ct. 1939) ; cf. RestateMrent, Trusts \& 242, at 742 (1935) ("the skill and success of the trustee in administering the trust.") One fund's management fee is geared, in part, to the performance of the management company as measured by the success of the management in surpassing the Dow Jones Industrial Average. The DeVegh Fund pays a regular management fee of one half of one per cent and an additional one half of one per cent if the performance of the Fund's shares over the course of a year as measured by its net asset value exceeds the Dow Jones Industrial Average by two points. See May, Observations, 193 Comsarercial and Financial Chronicle 968 (1961). 
the amount of the fund's assets. But since prices of securities generally have risen in recent years, ${ }^{90}$ an increase in the net asset value of fund shares, in itself, would not indicate the quality of the management company's performance. ${ }^{11}$ And since funds differ in their investment objectives with some stressing speculative common stock investments and those at the other end of the spectrum concentrating on high income-yielding bonds and preferred stock, ${ }^{92}$ it would be misleading to assess a management company's performance by comparing the fluctuations in the net asset value of fund shares with those of the stock market average. Rather, an effort should be made to compare the fund's performance with that of funds having similar investment objectives for comparable but lengthy periods of time-lengthy since the prudence of particular investment decisions might not be immediately evident. ${ }^{93}$ Similarly, a court might compare the size of fees paid by like funds. ${ }^{94}$ If the management company were undercompensated during the early period of the fund's growth, however, allowance might be made by subsequently permitting it to recoup. ${ }^{05}$

The cost to the management company of providing investment advice might also be considered pertinent in determining the reasonableness of the fee since such costs tend to reflect the amount of labor contributed to the fund. ${ }^{90}$ When

90. See Forbes, supra note 83, at 15 (chart indicating that Standard \& Poor's 500 Stock Average more than doubled in the long bull market from 1953 to 1961).

91. See Forbes, stipra note 83 , at 15.

92. See Lobell, The Mutual Fund: A Structural Analysis, 47 VA. L. REv. 181, 182 n.4 (1961).

93. See, e.g., the evaluation of the performance of various funds in Forbes, supra note 83 , at 17-23. The results were based on five distinct phases of the stock market in the period since September, 1953; three periods when the market was rising; two when it was declining.

94. Koplar v. Warner Bros. Pictures, 19 F. Supp. 173 (D. Del. 1937) (a stock bonus plan for executives was upheld partly upon a finding that the compensation was comparable to that prevalent in the industry); of. 4 Mertens, Federal Inconse Taxation $\$$ 25.72 (rev. ed. 1960) ; Baker, $A$ 'Just Gange' for Executive Compensation, 22 Harv. Bus. REv. 75 (discusses use of statistical data to draw comparisons between companies in the same line of business). Cf. Meiselman v. Eberstadt, 170 A.2d 720, 723 (Del. Ch. 1961) ("To" say that the officers are receiving consideration amounting to somewhat more than the average salaries found in the industry, on a time spent basis, is not to say that it is necessarily excessive."). The percentage fee charged by investment advisers generally may be lower than that charged by private counseling firms. See Lobell, Rights and Responsibilities in the Mutual Fund, 70 Y AIE L.J. 1258, 1262 n.17 (1961). But the services performed by private investment counsel differ substantially from those performed by a mutual fund management company, Thus, in evaluating the reasonableness of a particular fee charged a fund by an investment adviser, a comparision should not be made with the costs of obtaining private counseling.

95. See Lobell, supra note 92, at 191; Lobell, supra note 94, at 1287.

96. Cf. 4 MerTens, op. cit. supra note 94 , at $\$ 25.71$ (extent and scope of employee's work relevant). In fixing compensation which will be awarded to a trustee, a court will examine "the amount and difficulty of the service rendered by the trustee." 3 ScorT, TRUsts \$242, at 1929 (2d ed. 1956). But cf. Meiselman v. Eberstadt, 170 A.2d 720, 723 (Del. Ch. 1961) ("It is very difficult for me to say that the value of the services here rendered by 
a fund is first established and its assets are limited, an investment adviser might sustain expenses equal to or even in excess of remuneration based on a percentage of fund assets. ${ }^{97}$ As the assets of the fund increase, however, the costs of managing the fund's portfolio are not likely to rise proportionately. ${ }^{98}$ Partial recognition of the fact that management costs do not increase commensurately with the size of fund assets is reflected by the adoption of a "sliding-scale" fee arrangement by some funds. ${ }^{90}$ The typical formula provides that as a fund's assets reach higher stipulated levels, the percentage of fund assets upon which the management fee is based decreases. ${ }^{100}$ In evaluating the reasonableness of the fee paid to a management company which renders advisory services to more than one fund, ${ }^{101}$ costs would be particularly preferable to total assets as a yardstick. Much of the effort required to supervise one fund would not require duplication in the management of the others. ${ }^{102}$

the officers is to be automatically equated to the percentage of time formally devoted to Fund.").

97. See Lobell, supra note 92 , at 191 and n.36.

98. See Jaretzki, supra note 86 , at 1036; Bus. Week, May 16, 1959, p. 155 ("Most mutual fund men say $\ldots$ it costs very little more to manage a $\$ 400$-million fund than one with \$100-million.").

99. See May, Observations, 193 Commerctal and Financial Chronicle 968 (1961) ("Of the 214 leading open-end investment companies, only 43 now operate under a management fee formula which is variable. Practically all of the latter follow the scale technique.").

100. Ibid. (The Lazard Fund adopted "a new investment advisory contract providing, in lieu of the present annual $1 / 2 \%$ on all net assets, for a scale of fees involving a reduction from the $1 / 2 \%$ on the first $\$ 100$ million of net assets to $\$ / 8 \%$ on the next $\$ 50$ million, and $1 / 4 \%$ on the amount above $\$ 150$ million.").

101. Cf. Plaintiff's Complaint, pp. 5-6, Saminsky v. Long, Aug. 9, 1960, Sup. Ct., N.Y. (It is alleged that the investment adviser performs the management services for three funds.).

102. Cf. Taussig v. Wellington Fund, Inc., 187 F. Supp. 179, 187 (D. Del. 1960) (Wellington Co., Itd. serves as investment adviser to the Wellington Equity Fund and charges a fee of one half of one per of the assets of the Fund. "At the date of the complaint, the personnel of Wellington, Ltd., consisted of seven part-time account supervisors, counsellors, and executives; six part-time economists, statisticians and research personnel; and 16 other part-time personnel, it being anticipated that the persons employed by the Wellington Company in its investment advisory function for Wellington Fund would serve in a similar capacity with Wellington, Ltd."); The Economist, Sept. 16, 1961, p. 1086, col. 2 (In the United Kingdom mergers of investment trusts stemming from the same management trust have been arranged primarily to reduce expenses.). 